DOI: https://doi.org/10.32838/2523-4803/70-2-60

удК 352(082)

\title{
Пащенко Ю.Е.
}

доктор економічних наук, професор,

Таврійський національний університет імені В.І. Вернадського

\section{Pashchenko Yurii}

Tavria National University named after V.I. Vernadsky

\section{МАКРОЕКОНОМІЧНІ ПОКАЗНИКИ РОЗВИТКУ УКРАЇНИ}

Стаття є однією із цииклу статей, які аналізують економічний розвиток України за період незалежності 1992-2018 рр. Передбачається дослідити макроекономічні показники, економічні показники галузей реального сектору економіки України, систематизувати причини невдач і очінити можливості ефективного входження України в ринкову економіку. Досліджено макроекономічний рівень розвитку України. Показано тендениії $і$ виявлено основні причини стійкого зниження чисельності населення, його реальних доходів, ВВП, зростання державного боргу, погіршення платіжного балансу. До отримання політичної та економічної незалежності Україна займала одне з провідних місиь серед європейських країн. Непідготованість влади до ринкової економіки призвела до глибокої кризи керування $i$, як наслідок, до обвалу економіки. Для розроблення довгочасної, науково обтрунтованої сочіально-економічної стратегії виходу з економічної кризи необхідно зробити якісний комплексний аналіз економіки Украӥни за період незалежності, виявити тенденції, реалї, причини невдач, визначити ресурси і можливості, після чого позначити поетапні пріоритетні напрями виходу України з тривалої кризи.

Ключові слова: територія, населення, реальні доходи, валовий внутрішній продукт, бюджет, платіжний баланс, державний борг.

Постановка проблеми. До отримання політичної та економічної незалежності Україна займала одне з провідних місць серед європейських країн. Природні багатства, висококваліфікований трудовий потенціал, різноманітні виробничо-технічні, економічні і торговельні зв'язки 3 багатьма країнами світу давали Україні змогу динамічно і високими темпами комплексно розвивати свою економіку, починаючи від сировинних галузей до таких видів висококваліфікованого виробництва, як авіаційне та ракетобудування, суднобудування, виробництво сучасної продукції воєнно-промислового комплексу та ін.

Непідготованість влади до ринкової економіки призвела до глибокої кризи керування i, як наслідок, до обвалу економіки. Для розроблення довгочасної, науково обгрунтованої соціально-економічної стратегії виходу 3 економічної кризи необхідно зробити якісний комплексний аналіз економіки України за період незалежності, виявити тенденції, реалії, причини невдач, визначити ресурси і можливості, після чого визначити поетапні пріоритетні напрями виходу України з тривалой кризи.

Аналіз останніх досліджень і публікацій. Дослідженням макроекономічних показників займаються як провідні академічні, так і галузеві інститути, інформаційні та дослідницькі центри, публічні аудити та інші організації в різних галузях економіки.

Шляхи вирішення багатьох проблем підвищення ефективності економіки України в умовах ринкових перетворень висвітлено у працях вітчизняних учених: В.А. Алампиєва, В. Базилевіча, О.В. Бандура, Б.В. Бурківського, В.М. Геєця, О.С. Ємельянова, В.С. Найдьо- нова, Ю.В. Пахомова, І.Ф. Родіонової, О.П. Тищенко, В.I. Усика та ін.

Ураховуючи невизначеність і нестійкість економічної системи України, аналітичні дослідження в галузі макроекономіки необхідно постійно поглиблювати та вдосконалювати.

Формулювання цілей статті. Мета статті - встановити основні тенденції, які негативно впливають на макроекономічні показники України, виявити причини, оцінити наслідки і підготувати рекомендації щодо скорішого оздоровлення економіки України.

Виклад основного матеріалу. Україна є однією з найбільших європейських країн, що володіють потужним територіальним, природно-географічним, людським, промисловим, транспортним і сільськогосподарським потенціалом. До набуття незалежності вона займала п'яте місце в Європі за обсягом ВВП. Для успішного самодостатнього розвитку Україні вистачало всього: найрізноманітніших природно-сировинних ресурсів, практично всіх елементів таблиці Менделєєва в надрах, найродючіших чорноземів, досить великого масиву лісових угідь, надзвичайно вигідного географічного розташування 3 позицій міжнародного транспортного сполучення. Промисловість України була представлена повним спектром галузей - від гірничодобувної і до таких високотехнологічних галузей, як суднобудування, авіакосмічна промисловість, приладобудування. Великий обсяг продукції виконується підприємствами воєнно-промислового комплексу (ВПК). Торгово-економічні, наукові зв'язки Україна мала з більшістю країн світу. 
В Україні сформувався висококваліфікований виробничий і науково-технічний потенціал, тому 3 набуттям незалежності у неї були всі шанси для швидкого досягнення економічних і соціальних стандартів, за яких країні не потрібно було б проситися в СС, iї б запросили туди на правах рівноправного члена. Є багато прикладів, коли повністю зруйновані в період Другої світової війни країни за п'ять-сім років повністю відновили свою економіку і досягли більш високих, аніж у передвоєнний період, показників.

В Україні на початок перебудови ніяких руйнувань не спостерігалося. Стимулюючим чинником для досягнення Україною європейських стандартів різними світовими фінансовими інститутами надавалися кредити. На жаль, Україна, яка порівняно легко отримала незалежність і успадкувала від СРСР хоча й застарілий, але все ж таки потужний виробничо-економічний потенціал, у силу низки об'єктивних, але великою мірою суб'єктивних причин, не тільки не змогла використати широкі можливості самостійного розвитку, а й різко знизила всі економічні і соціальні показники. Стагнація економічного розвитку призвела до втрати як політичної, так і економічної незалежності країни, відсунула на невизначений термін перспективу входження України в ЄС як рівноправного члена. Підіб'ємо підсумки економічного розвитку за 28-річний період незалежності.

Територія. Загальна площа України на 01.01.1992 становила 603,6 тис км², або 5,7\% території Європи і 0,44\% території світу. Через анексію Криму (27 тис кв. км) та окупацію частини Донецької і Луганської областей $(19,2$ тис кв. км) територія країни становить 557,5 тис км². Площа виняткової економічної зони України становить 46,2 тис км², що становить 7,2\% території 2013 р. Це більше, ніж площа Естонії, Нідерландів або Швейцарії.

Населення України і демографічна ситуація. Головним ресурсом національного багатства будь-якої країни по праву вважається населення. Воно скоротилося за роки незалежності (1992-2019 pp.), за даними Держстату України, з 51,3 млн до 42,1 млн осіб. Без урахування Криму та окупованої частини Донбасу населення України буде 38,1 млн осіб. Більша частина працездатного населення знаходиться на постійних заробітках у країнах ЄС та Росії. За підрахунками експертів, в Україні постійно проживають 33-35 млн осіб. Розрахунки проводилися за споживанням хліба. Офіційний перепис населення України відбувся тільки в 2001 p.

За повідомленням Держстату України, динаміка чисельності населення характеризується такими показниками.

За 28 років Україна втратила понад 10 млн осіб, що становить п'яту частину населення. Викликає занепокоєння той факт, що скорочення населення після 1992 р. прийняло в Україні постійний характер.

Нижче представлено демографічні зміни в Україні, розраховані Інститутом демографії та соціальних досліджень, за 2018 р. Згідно 3 нашою оцінкою, на кінець 2018 р. населення України становило 42153656 осіб. За 2018 р. населення України зменшилося приблизно
Таблиця 1

Населення України, 1992-2019 рр.

\begin{tabular}{|c|c|c|c|}
\hline \multirow{2}{*}{ Дата } & \multirow{2}{*}{$\begin{array}{c}\text { чисельність } \\
\text { (тис осіб) }\end{array}$} & \multicolumn{2}{|c|}{$\begin{array}{c}\text { зріст (+) спад (- ) } \\
\text { до попереднього року }\end{array}$} \\
\cline { 3 - 4 } & & тис осіб & \% \\
\hline на 01.01.1992 & 51337,4 & & \\
\hline на 01.01.1995 & 51728,4 & -386.0 & $-0,741 \%$ \\
\hline на 01.01.2000 & 49429,8 & -488.3 & $-0.978 \%$ \\
\hline на 01.01.2005 & 47280,8 & -341.6 & $-0.717 \%$ \\
\hline на 01.01.2010 & 45962,9 & -180.8 & $-0.392 \%$ \\
\hline на 01.01.2011 & 45778,5 & -184.4 & $-0.401 \%$ \\
\hline на 01.01.2012 & 45633,6 & -144.9 & $-0.317 \%$ \\
\hline на 01.01.2013 & 45553,0 & -80.6 & $-0.177 \%$ \\
\hline на 01.01.2014 & 45426,2 & -126.8 & $-0.278 \%$ \\
\hline на 01.01.2015 & 42928,9 & -2497.3 & $-5.497 \%$ \\
\hline на 01.01.2016 & 42617,3 & -168.4 & $-0.392 \%$ \\
\hline на 01.01 .2017 & 42500,0 & $-260,5$ & $-0,613$ \\
\hline на 01.01 .2018 & 42307,6 & $-192,4$ & $-0,454$ \\
\hline на 01.01 .2019 & 42153,6 & $-154,0$ & $-0,365$ \\
\hline
\end{tabular}

на 154 тис осіб. Ураховуючи, що населення країни на початок року оцінювалося у 42307656 осіб, річний приріст становив $-0,36 \%$.

Ось основні демографічні показники України за 2018 p.:

- народжуваність: 456500 осіб;

- смертність: 646884 особи;

- природний приріст населення: -190 384 особи;

- міграційний приріст населення: 36385 осіб, у середньому 100 осіб на день.

Насторожує також той факт, що Україна за рівнем смертності перевищує рівень народжуваності. Для того щоб покоління дітей кількісно замінило покоління батьків, з урахуванням дитячої та підліткової смертності, 100 жінок повинні народжувати 213-215 дітей, а у нас на 100 жінок припадає 150 дітей.

Середня тривалість життя при народженні (для обох статей) в Україні становить 68,6 року. Це нижче середньої тривалості життя по світу, яка знаходиться на рівні приблизно 71 рік (за даними відділу народонаселення Департаменту ООН з економічних і соціальних питань). Наприклад, в Японії, Скандинавських країнах середня тривалість життя становить 82 роки.

Доходи та якість життя населення. На показник умов і якості життя населення передусім впливає його економічне благополуччя. Розглянемо деякі показники, що характеризують доходи населення. Середньомісячну номінальну заробітну плату в національній валюті та доларах США приведено в табл. 2.

За 10 років номінальна зарплата в національній валюті збільшилися в 4,6 рази, у доларах США - в 1,3 рази. Різні темпи росту зумовлені обвалом гривні по відношенню до долара США за 2014-2015 рр. в 2,7 рази. Інфляція за цей же період становила понад 40\%. До початку 2019 р. Україна за рівнем середньої та мінімальної заробітної плати досягнула рівня 2011-2012 pр.

Певний інтерес викликає порівняння показників середньої заробітної плати України і найбільш розви- 
Динаміка середньої і мінімальної зарплати в Україні

\begin{tabular}{|c|c|c|c|c|c|}
\hline \multirow{2}{*}{ роки } & \multirow{2}{*}{$\begin{array}{c}\text { Курс долара } \\
\text { грн } \\
\end{array}$} & \multicolumn{2}{|c|}{ Номінальна заробітна плата } & \multicolumn{2}{|c|}{ Мінімальна заробітна плата } \\
\hline & & грн & дол. & грн & дол. \\
\hline 2010 & 7,93 & 2239 & 282 & 863 & 121,0 \\
\hline 2011 & 7,97 & 2633 & 330 & 960 & 126,0 \\
\hline 2012 & 8,20 & 3026 & 362 & 1004 & 138,3 \\
\hline 2013 & 8,30 & 3265 & 393 & 1134 & 146,8 \\
\hline 2014 & 16,38 & 3480 & 212 & 1218 & 74,4 \\
\hline 2015 & 25,06 & 4195 & 168 & 1378 & 55,0 \\
\hline 2016 & 25,55 & 5183 & 202,8 & 1600 & 62,6 \\
\hline 2017 & 26,62 & 7392 & 277,7 & 3200 & 120,2 \\
\hline 2018 & 27,20 & 8865 & 325,9 & 3723 & 136,9 \\
\hline 2019 І кв. & 27,25 & 9400 & 344,9 & 4173 & 153,1 \\
\hline
\end{tabular}

нутих і багатих країн світу. У 2018 р. заробітна плата в Швейцарії становила 5426 дол. США, Австралії 3 306, Об'єднаних Арабських Еміратах - 3 182, Норвегії - 3 176, Данії - 3 068, США - 2 835, Японії - 2 495, Німеччині - 2 425, Швеція - 2 360, Франції - 2121 дол. США. Україна за цим показником серед країн світу займає 127-е місце, що у 15-20 разів менше, ніж у найбільш розвинутих країнах світу.

Більша частина населення України знаходиться практично у бідності. У рейтингу країн світу за рівнем мінімальної заробітної плати країна знаходиться на 81-му місці (141,9 дол.). Наприклад, у Швейцарії - 3424 дол., Люксембургу - 2397 дол., Німеччині - 1779 дол., Великобританії - 1724 дол., Франції - 1472 дол., США 1160 дол.; у Польщі - 603 дол., Чехії - 573 дол., Угорщині - 533 дол., Латвії - 516 дол., Литві - 480 дол. На мінімальну зарплату в Україні не проживеш, тому включається тіньовий сектор економіки, за якого для зняття податкового преса працюючим виплачується основна зарплата в розмірі мінімальної, а реальну видають у конвертах. Держава, не отримуючи повною мірою податків, не може створити нормальний пенсійний фонд. У результаті люди, що гідно відпрацювали все життя, отримують жебрацьку пенсію, на яку прожити неможливо. Виникла економіка 3 перекрученою системою оплати праці і пенсій. А з урахуванням несумлінності органів влади ці деформації посилюється. За експертними оцінками, продукт тіньової економіки i, відповідно, іiі доходи в Україні становлять від 40\% до 50\%.

Інтегральну оцінку економічного складника якості та рівня життя дає показник рівня ВВП на душу населення. Лише за два роки (2014-2015 рр.) абсолютний обсяг ВВП опустився зі 183 млрд дол. до 91 млрд дол., тобто в два рази. ВВП на душу населення скоротився 34030 дол. до 2115 дол., або в 1,9 рази (різниця в темпах падіння пов'язана зі скороченням населення). За даними МВФ, Україна у 2018 р. за розміром ВВП на душу населення займала 134-е місце у світі.

За показником рівня щастя Україна опинилася у 2018 р. на 138-му місці зі 154-х. За основу визначення міжнародного індексу щастя беруться добробут людей, стан навколишнього середовища та низка інших показників. Незмінними лідерами рейтингу за цим показником лишаються країни Північної Свропи. Цього року на першому місці у рейтингу Фінляндія, на другому - Норвегія, на третьому - Данія. Далі до топ-10 увійшли Ісландія, Швейцарія, Нідерланди, Канада, Нова Зеландія, Швеція та Австралія. Порівняно з 2017 р. наша країна тільки за рік опустилася на шість пунктів (зі 132-го місця).

Підсумковим показником для оцінювання довгострокового прогресу є індекс людського розвитку (ІЛР), який вимірюється у трьох основних площинах: довготривале та здорове життя, доступ до знань, гідний рівень життя. Довге і здорове життя вимірюється середньою тривалістю життя. Рівень знань вимірюється середньою кількістю років, витрачених на освіту дорослим населенням, а доступ до навчання та знань - очікуваними роками навчання для дітей-першокласників, тобто загальною кількістю років навчання, на які дитина, що досягає шкільного віку, може розраховувати, якщо певні моделі вікових показників зарахування до школи залишаються незмінними протягом життя дитини. Рівень життя вимірюється валовим національним доходом (ВНД) на душу населення в доларах. В Україні спостерігається тенденція до поступового поліпшення у сфері людського розвитку, але попереду ще чимало роботи. Країна перебуває на 88-му місці у рейтингу зі 189 країн, для яких вираховується ІЛР. Проте такий показник усе ж дав країні змогу потрапити у вищу категорію людського розвитку.

Валовий внутрішній продукт (ВВП). Валовий внутрішній продукт (ВВП) $є$ основним, найбільш повним офіційним показником суспільного добробуту. Він дає уявлення про загальний матеріальний добробут нації, оскільки чим вище рівень виробництва, тим вище добробут країни. Проте у ВВП, як і у багатьох інших статистичних показників, є недоліки. Як відомо, валовий внутрішній продукт не враховує результати виробництва в домашньому господарстві, у натуральному i тіньовому секторах економіки. Оскільки ці види діяльності існують у будь-якій країні, то можна сказати, що реальний обсяг благ, вироблених у суспільстві, завжди трохи більше ВВП. Країни з менш розвиненим товарним господарством і з великим обсягом тіньової економіки мають відносно більший обсяг благ, неврахованих у ВВП. У валовому продукті враховується виробництво будь-яких товарів і послуг. Виробництво, однак, часто 
веде до руйнування навколишнього середовища, підриву здоров'я людей. Негативні зовнішні ефекти виробництва, як правило, не знаходять відображення у ВВП. Державні витрати не завжди носять творчий характер. Важко, наприклад, відокремити виробництво озброєнь для забезпечення необхідної оборони і надлишкове виробництво військової техніки на догоду амбіціям або агресивним устремлінням керівництва країни.

Розглядаючи ВВП із цих позицій, можна сказати, що у цьому показнику завищені рівні добробуту. Проте, визнаючи недосконалість показника ВВП, можна стверджувати, що на даний момент це реальний, найбільш повний вимірювач як результатів зусиль суспільства з виробництва матеріальних благ, так і рівня його добробуту. Динаміку ВВП України в національній валюті, а також у доларах США представлено в табл. 3.

Номінальний ВВП у національній валюті за період 1990-2018 рр. постійно зростав (за винятком 2009 р., що зв'язано з кризовими явищами у 2008 р.). Постійне зростання ВВП пояснюється високими темпами інфляції. Реальний огляд темпів зростання ВВП дає його інтерпретація у доларовому еквіваленті. 32013 по 2015 р. обсяг ВВП скоротився в два рази. У 2017-2018 рр. спостерігається незначний зріст продукту, за якого з урахуванням високої інфляції досягнути обсягу ВВП 2013 р. можливо лише через п'ять-шість років. Ураховуючи, що країни $\mathrm{CC}$, які оточуюють Україну, з набагато більшою базовою величиною ВВП і темпами іiі зросту, наздогнати їх буде дуже проблематично.
У кінці 2020 р. аналітики МВФ передбачають наступну фінансову кризу, яка буде торкатися економік практично всіх країн світу. На їхню думку, єдина можливість уникнути серйозних наслідків для економіки й утримати зростання ВВП - відмовитися від допомоги світових центробанків і сподіватися на внутрішній peсурс. МВФ закликають країни «зі слабкою економікою», включаючи Україну, продовжувати провадити структурні реформи, щоб забезпечити стабільне зростання ВВП. Нагадаємо, реальний валовий продукт (ВВП) України в 2018 р. зріс на 3,3\% порівняно 3 2017 р. У 2017 р. зріст був на рівні 2,5\%.

Державні фінанси. Зведений бюджет України представлено державними та місцевими бюджетами (табл. 4).

За 2011-2018 pp. доходна частина зведеного бюджету збільшилася майже в три рази, у тому числі по державному бюджету - в 2,9, а місцевому - в 3,4 рази. Структура доходної частини зведеного бюджету (за винятком 2015 р.) практично не змінювалася: 77-78\% державний, 23-22\% - місцеві. У динаміці виконання зведеного бюджету спостерігалося перевищення видатків плюс кредитування над доходами. Дефіцит сальдо к ВВП коливався від 1,4\% до 4,6\%.

Динаміка структури видатків державного бюджету вказує на підвищення витрат на оборону в чотири рази, що пов'язано з проведенням антитерористичної операції на Сході України. Також зросли видатки на загальнодержавні функції керування - у 2,5 рази, на громадський порядок, безпеку та судову владу - у 1,5 рази.

Таблиця 3

Динаміка ВВП України

\begin{tabular}{|c|c|c|c|c|c|}
\hline \multirow{2}{*}{ роки } & \multicolumn{2}{|c|}{ Номінальний ВВП } & \multirow{2}{*}{ Населення, тис осіб } & \multicolumn{2}{|c|}{ ВВП на одну особу } \\
\cline { 2 - 3 } & млн. грн & млн дол. США & & грн & дол. США \\
\hline 1995 & 54516 & 37009 & 50932 & 1071 & 727 \\
\hline 1996 & 81519 & 44559 & 50650 & 1578 & 980 \\
\hline 1997 & 93365 & 41883 & 50293 & 2057 & 840 \\
\hline 1998 & 102583 & 31581 & 49876 & 2639 & 639 \\
\hline 1999 & 130442 & 31262 & 49426 & 3473 & 638 \\
\hline 2000 & 170070 & 38009 & 48972 & 4210 & 783 \\
\hline 2001 & 204190 & 42393 & 48528 & 4696 & 881 \\
\hline 2002 & 225810 & 50133 & 48101 & 6605 & 1051 \\
\hline 2003 & 267344 & 50130 & 47692 & 7272 & 1367 \\
\hline 2004 & 345113 & 64883 & 47452 & 9371 & 1828 \\
\hline 2005 & 441452 & 86142 & 47105 & 11630 & 2303 \\
\hline 2006 & 544153 & 107753 & 46788 & 20494 & 3068 \\
\hline 2007 & 720731 & 142719 & 46509 & 19832 & 3891 \\
\hline 2008 & 948056 & 179992 & 46258 & 23600 & 2545 \\
\hline 2009 & 913345 & 117228 & 46053 & 28813 & 2974 \\
\hline 2010 & 1082569 & 136419 & 45871 & 30912 & 3570 \\
\hline 2011 & 1316600 & 163160 & 45693 & 31988 & 3856 \\
\hline 2012 & 1408889 & 175781 & 45577 & 35834 & 4030 \\
\hline 2013 & 1454931 & 183310 & 45483 & 46210 & 3014 \\
\hline 2014 & 1566728 & 131805 & 43722 & 55853 & 2115 \\
\hline 2015 & 1979458 & 90615 & 42835 & 80224 & 2185 \\
\hline 2016 & 2383182 & 93270 & 42668 & 42477 & 2640 \\
\hline 2017 & 2982920 & 112154 & 42269 & & 3095 \\
\hline 2018 & 3558706 & 130834 & & & \\
\hline
\end{tabular}


Структура зведеного бюджету України з 2011 по 2018 р., млн грн

\begin{tabular}{|c|c|c|c|c|c|c|c|c|c|}
\hline \multirow{3}{*}{ роки } & \multicolumn{3}{|c|}{ зведений бюджет, загалом } & \multicolumn{6}{|c|}{ у тому числі } \\
\hline & \multirow[b]{2}{*}{ доходи } & \multirow[b]{2}{*}{ видатки } & \multirow{2}{*}{$\begin{array}{c}\text { кредиту- } \\
\text { вання }\end{array}$} & \multicolumn{3}{|c|}{ державний бюджет } & \multicolumn{3}{|c|}{ місцевий бюджет } \\
\hline & & & & доходи & видатки & $\begin{array}{c}\text { кредиту- } \\
\text { вання }\end{array}$ & доходи & видатки & $\begin{array}{c}\text { кредиту } \\
\text { вання }\end{array}$ \\
\hline 2011 & 398554 & 416854 & 4758 & 314617 & 333460 & 4715 & 75936 & 83395 & 43 \\
\hline 2012 & 445525 & 482455 & 3856 & 346954 & 395682 & 3818 & 99471 & 96974 & 38 \\
\hline 2013 & 442789 & 505844 & 536 & 339180 & 403403 & 485 & 103609 & 92908 & 50 \\
\hline 2014 & 456067 & 523126 & 4972 & 957084 & 430218 & 4919 & 98983 & 92908 & 53 \\
\hline 2015 & 652031 & 679871 & 3058 & 534695 & 576911 & 2951 & 117336 & 102960 & 107 \\
\hline 2016 & 782748 & 835590 & 1841 & 616285 & 684743 & 1662 & 166473 & 150847 & 179 \\
\hline 2017 & 1016788 & 1068760 & 2122 & 793265 & 839244 & 1871 & 223523 & 219516 & 251 \\
\hline 2018 & 1184278 & 1250174 & 1893 & 928109 & 985842 & 1514 & 256170 & 264331 & 379 \\
\hline
\end{tabular}

Протилежна тенденція спостерігається з видатками на економічну діяльність - їхня частка зменшилася вдвічі. Також скоротилися витрати на охорону здоров'я - в 2 рази, освіту - в 2,3 рази. Різко знизилися видатки на капітальні вкладення.

Найбільший приріст надходжень до зведеного бюджету в 2018 р. відбувся за рахунок росту податкових надходжень, які зросли на 158 млрд грн, або на 19,1\%, завдяки вищим надходженням від ключових податків. Доходи від податку та збору на доходи фізичних осіб збільшилися на 44,2 млрд грн $(+23,8 \%$ порівняно 3 2017 р.), податкунаприбуток-на 32,8 млрдгрн $(+44,7 \%$,), ПДВ (сальдо) - на 60,5 млрд грн $(+19,3 \%)$, акцизного податку - на 11,2 млрд грн (+9,2\%).

Водночас доходи від рентної плати зменшилися на 1,0 млрд грн, або на 2\%, унаслідок утворення наприкінці 2017 р. переплати з рентної плати за видобування природного газу та її погашення протягом 2018 р.

Неподаткові надходження у 2018 р. проти 2017 р. також зросли на 38,2 млрд грн.

Податок та збір на доходи фізичних осіб (далі - ПДФО) є одним із бюджетоформуючих податків, із 2011 по 2018 р. його частка у ВВП зросла на 2,0 в. п., до 6,5\% ВВП. Цей податок є стабільним джерелом наповнення бюджетів, і в кризові роки його надходження не схильні до зменшення як у номінальному виразі, так і по відношенню до ВВП.

Обсяг надходжень податку на додану вартість 3 урахуванням бюджетного відшкодування за 2018 р. збільшився на 19,3\% до 2017 р. і становив 374,5 млрд грн, у тому числі приріст надходжень податку на додану вартість із вироблених в Україні товарів (робіт, послуг) становив $+14,9 \%$, податку на додану вартість з увезених на територію України товарів $-+17,9 \%$, бюджетного відшкодування податку на додану вартість $-+9,7 \%$.

Платіжний баланс. Наступним етапом макроекономічного аналізу є дослідження платіжного балансу. Це один із найважливіших індикаторів, що відображає торговельні відносини між резидентами й нерезидентами та свідчить про насиченість економіки країни іноземною валютою. Платіжний баланс країни надається як статистичний звіт, в якому у систематизованому вигляді наведено зведені відомості щодо зовнішньоекономіч- них операцій резидентів країни з нерезидентами запевний період. Динаміку основних показників платіжного балансу в аналітичній формі відображено в табл. 5.

Чільні компоненти платіжного балансу групуються за двома рахунками: рахунком поточних операцій i рахунком операцій із капіталом та фінансових операцій. Рахунок поточних операцій віддзеркалює рух за кордон або з-за кордону товарів, послуг і трансфертних платежів. Рахунок руху капіталів виявляє рух позикових коштів і фінансових активів: по-перше, відтік капіталів; по-друге, приплив капіталів.

Динаміка платіжного балансу України за період із 2010 по 2018 р. була вкрай нестійкою. Але залишилася тенденція до зростання негативного сальдо в балансі поточних операцій (3 - 3,0 млрд дол. до -4,4 млрд дол.). На негативне сальдо балансу поточних платежів суттєво вплинув торговельний баланс (різниця між експортом та імпортом товарів), дефіцит якого в 2018 р. становив 12,7 млрд дол.

Україна належить до експортоорієнтованої держави. Приблизно половина виробленої в Україні продукції продається за кордон, про що свідчить співвідношення ВВП до експорту 2018 р.: експорт товарів становив 43,3 млрд дол., або 48\% від ВВП. Проте наша країна переважно експортує не готову продукцію, а лише сировину (сталь, зерно, руду), і в цьому ії ключова проблема. У 2018 р. експорт становив 42\% від ВВП, показник за 2018 р. на рівні 48\%. Ще з 90-х років Україна вибрала найлегший спосіб отримання доходів - від продажу неготової продукції замість розвитку технологічного виробництва.

Усі країни - виробники сировини перебувають у зоні ризику: їхні основні товари можуть у будь-який момент подешевшати та обвалити економіку. Сировинні країни не контролюють власний розвиток, тому Україна стала черговою жертвою сировинної залежності: якщо вона не вироблятиме складної продукції та продаватиме тільки сировину, обов'язково трапиться криза.

У 2018 р. імпорт у загальному товарообігу становив 49,0 млрд дол. і по відношенню до ВВП займав 51,4\%. Це вказує на величезну залежність внутрішнього ринку від імпортованої продукції, що є доволі небезпечною тенденцією. 
Динаміка платіжного балансу України, млн дол. США

\begin{tabular}{|l|c|c|c|c|c|c|c|c|c|}
\hline & \multicolumn{9}{|c|}{ роки } \\
\cline { 2 - 10 } & $\mathbf{2 0 1 0}$ & $\mathbf{2 0 1 1}$ & $\mathbf{2 0 1 2}$ & $\mathbf{2 0 1 3}$ & $\mathbf{2 0 1 1 4}$ & $\mathbf{2 0 1 5}$ & $\mathbf{2 0 1 6}$ & $\mathbf{2 0 1 7}$ & $\mathbf{2 0 1 8}$ \\
\hline А. Рахунок поточних операцій & -3016 & 10233 & 14335 & 16518 & 4596 & 1616 & -1340 & -2442 & -4367 \\
\hline Баланс товарів та послуг & -3982 & 10145 & 14346 & 15634 & -4606 & -2362 & -6453 & -8644 & -11367 \\
\hline Баланс товарів & -9597. & 18031 & 21846 & 22128 & -7128 & -3455 & -6942 & -9663 & -12714 \\
\hline Експорт товарів & 47299 & 62383 & 64427 & 59106 & 50552 & 35420 & 33560 & 39701 & 43341 \\
\hline Імпорт товарів & 56896 & 80414 & 86273 & 81234 & 57680 & 38875 & 40502 & 49364 & 56055 \\
\hline Баланс послуг & 5615 & 7886 & 7500 & 6494 & 2522 & 1093 & 489 & 1019 & 1347 \\
\hline Експорт послуг & 18327 & 21269 & 22089 & 22613 & 14884 & 12442 & 12448 & 14167 & 15794 \\
\hline Імпорт послуг & 12712 & 13383 & 14589 & 16119 & 12362 & 11349 & 11959 & 13148 & 14447 \\
\hline Баланс первинних доходів & -2009 & -3796 & -2965 & -3033 & -1531 & 375 & 1477 & 2579 & 3348 \\
\hline Надходження & 4715 & 5485 & 7082 & 7767 & 5503 & 5786 & 6889 & 9329 & 11860 \\
\hline Виплати & 6724 & 9281 & 10047 & 10800 & 7034 & 5411 & 5412 & 6750 & 8512 \\
\hline Баланс вторинних доходів & 2975 & 3708 & 2976 & 2149 & 1541 & 3603 & 3636 & 3623 & 3652 \\
\hline Надходження & 4042 & 4751 & 4219 & 4129 & 3424 & 4573 & 4627 & 4811 & 4933 \\
\hline Виплати & 1067 & 1043 & 1243 & 1980 & 1883 & 970 & 991 & 1188 & 1285 \\
\hline В. Рахунок операцій з капіталом & 188 & 101 & 40 & -60 & 400 & 456 & 92 & -4 & 37 \\
\hline Чисте кредитування (+) & -3016 & -10233 & -14335 & -16518 & -4596 & 1616 & -1340 & -2442 & -4367 \\
\hline Запозичення (-) & -2828 & 10132 & 14295 & 16578 & 4196 & 2072 & -1248 & -2446 & -4330 \\
\hline С. Фінансовий рахунок & -7859 & -7677 & -10120 & -18601 & 9111 & 1223 & -2594 & -5012 & -7207 \\
\hline Прямі інвестиції (сальдо) & -5759 & -7015 & -7195 & -4079 & -299 & -3012 & -3268 & -2593 & -2360 \\
\hline Портфельні інвестиції (сальдо) & -4342 & -1569 & -4689 & -8787 & 2700 & -367 & -293 & -1800 & -2080 \\
\hline Інші інвестиції (сальдо) & 3593 & 1878 & 3157 & -6375 & 7243 & 4263 & 392 & -137 & -1218 \\
\hline Помилки та упущення & 1351 & 971 & 1393 & -640 & 533 & -339 & -575 & 482 & 1711 \\
\hline Д. Зведений баланс & 5031 & -2455 & -4175 & 2023 & -13307 & 849 & 1346 & 2566 & 2877 \\
\hline
\end{tabular}

Дані з 2014 р. наведено без урахування АР Крим та окупованих територій Донеиької та Луганської областей.

У річному вимірі темпи зростання імпорту прискорилися, випереджаючи приріст експорту. Насамперед відбулося розширення енергетичного імпорту - у півтора рази. На внутрішньому ринку визначився дефіцит вугілля, велика частина якого в попередні роки поставлялася з Донбасу. Водночас у світі підвищилися ціни на енергоресурси.

Після революційних подій, військових конфліктів та анексії території інвестори не тільки припинили інвестувати в економіку, а й почали виводити інвестиції 3 нашої країни. Така тенденція сприяла швидкому краху економіки. Керівництво країни вирішило рятувати ситуацію не структурними змінами, а завдяки співпраці 3 міжнародними фінансовими організаціями які, надаючи кредити, почали диктувати вигідні саме їм умови i, таким чином, заганяти Україну в «боргову яму».

Валовий та державний борг України. Успішність розвитку економіки, забезпечення суверенності держави великою мірою залежать від обсягу боргових обов'язків, а також від уміння керувати і маневрувати боргами. Зупинимося на понятті й характеристиці основних видів боргів. Розрізняють сукупний борг, державний борг, гарантований державний борг, інші міжгалузеві борги.

Валовий зовнішній борг (ВЗБ) станом на певну дату являє собою загальний обсяг заборгованості за всіма існуючими зобов'язаннями, що мають бути сплачені боржниками та які є зобов'язаннями резидентів економіки країни перед нерезидентами. Інакше кажучи, це загальна заборгованість країни за зовнішніми позиками та невиплаченими за ними процентами.

Валовий зовнішній борг містить у собі як державний зовнішній борг (уряду та Нацбанку), так і недержавний (банків, національних та акціонерних компаній тощо). Динаміку валового зовнішнього боргу (ВЗБ) i його співвідношення з ВВП представлено в табл. 6 .

Аналізуючи динаміку відповідних показників, можна стверджувати про загальне зменшення валового зовнішнього боргу. Проте, незважаючи на зменшення загального боргу, спостерігається негативна тенденція до його збільшення відносно ВВП. Починаючи з 2016 р. намітилася позитивна тенденція до зниження рівня ВЗБ відносно ВВП зі 131\% до 87,8\%. Доходи, отримані від реалізації виробленого продукту, мають покривати зобов'язання. Допущення дисбалансів $є$ неприпустимим, оскільки погашення боргу доведеться здійснювати за рахунок наступних запозичень, а після цього вихід тільки один - дефолт.

Не зменшуючи важливість звідного показника валового зовнішнього боргу особливо слід визначити у його складі державний і гарантований державний борг. Саме від рівня державної заборгованості та можливості своєчасного ії̈ погашення залежить інвестиційна і фінансова привабливість держави з боку міжнародних партнерів. Чинник фінансової стабільності та надійності дає змогу активно взаємодіяти з усіма міжнародними фінансовими інститутами, привабить інвесторів, що за розумного керівництва дасть змогу забезпечити 
Динаміка валового зовнішнього боргу і ВВП України (млн дол. США)

\begin{tabular}{|c|c|c|c|}
\hline Роки & Валовий зовнішній борг (ВЗБ) & Валовий внутрішній продукт (ВВП) & ВЗБ / ВВП \\
\hline на 31.12.2009 & 103396 & 117228 & $88.2 \%$ \\
\hline на 31.12.2010 & 117343 & 136419 & $86.0 \%$ \\
\hline на 31.12.2011 & 126236 & 163160 & $77.4 \%$ \\
\hline на 31.12.2012 & 135065 & 175781 & $76.8 \%$ \\
\hline на 31.12.20013 & 142079 & 183310 & $77.5 \%$ \\
\hline на 31.12.2014 & 126308 & 131805 & $95.8 \%$ \\
\hline на 31.12.2015 & 118729 & 90615 & $131.0 \%$ \\
\hline на 31.12.20016 & 113518 & 93270 & $121.7 \%$ \\
\hline на 31.12.20017 & 116578 & 112154 & $103.9 \%$ \\
\hline на 31.12.2018 & 114707 & 130834 & $87,8 \%$ \\
\hline
\end{tabular}

Динаміка сукупного державного боргу і ВВП України

\begin{tabular}{|c|c|c|c|c|c|c|}
\hline \multirow[t]{2}{*}{ Роки } & \multicolumn{2}{|c|}{ Загальний борг } & \multicolumn{2}{|c|}{ ВВП } & \multicolumn{2}{|c|}{$\begin{array}{c}\text { Співвідношення } \\
\text { загального боргу і ВВП }\end{array}$} \\
\hline & млрд грн & млрд дол. США & млрд грн & млрд дол. США & по грн, \% & по дол. США, \% \\
\hline на 31.12.2009 & 316,69 & 39,7 & 913,3 & 46,0 & 34,7 & 33,9 \\
\hline на 31.12 .2010 & 4322,2 & 54,3 & 1082,6 & 45,9 & 39,9 & 39,9 \\
\hline на 31.12.2011 & 473,1 & 59,2 & 1316,6 & 45,7 & 35,9 & 36,3 \\
\hline на 31.12.2012 & 515,5 & 64,5 & 1408,9 & 45,6 & 36,6 & 36,6 \\
\hline на 31.12 .2013 & 584,1 & 73,1 & 1454,9 & 45,5 & 40,1 & 39,9 \\
\hline на 31.12 .2014 & 1100,1 & 69,8 & 1566,7 & 43,7 & 70,2 & 52,9 \\
\hline на 31.12 .2015 & 1572,2 & 65,5 & 1979,5 & 49,8 & 79,4 & 72,0 \\
\hline на 31.12 .2016 & 1929,8 & 71,0 & 2383,2 & 42,7 & 81,0 & 76,3 \\
\hline на 31.12.2017 & 2141,7 & 76,3 & 2982,9 & 42,5 & 71,8 & 68,1 \\
\hline на 31.12.2018 & 2168,6 & 78,3 & 3558,7 & 42,3 & 60,9 & 59,8 \\
\hline
\end{tabular}

економічне зростання держави. Ураховуючи важливість показника державного боргу, докладніше зупинимося на його понятті і змісті.

Державний борг традиційно поділяють на зовнішній та внутрішній.

Зовнішній державний борг - заборгованість держави іншим країнам, міжнародним економічним організаціям та іншим особам. Державний зовнішній борг $\epsilon$ частиною валового зовнішнього боргу країни.

Внутрішній державний борг - заборгованість держави власникам державних цінних паперів та іншим кредиторам.

Гарантований державою борг - загальна сума боргових зобов'язань суб'єктів господарювання - резидентів України щодо отриманих та непогашених на звітну дату кредитів (позик), виконання яких забезпечено державними гарантіями.

Державний та гарантований державою борг не включає борги місцевих органів влади та державних підприємств, що не забезпечені державними гарантіями. Динаміку сукупного і державного боргу та його співвідношення з ВВП наведено в табл. 7.

У доларовому і гривневому еквіваленті структура державного боргу з 2009 р. практично не змінювалася, для зовнішнього боргу змінилася загалом із 66,8\% до $64,4 \%$. Збільшився загальний обсяг державного боргу. Так, загальний обсяг боргу з 2009 р. у доларовому еквіваленті зріс у два рази і досяг 78,3 млрд дол., у тому числі зовнішній борг зріс в 1,9 рази і досяг 50,0 млрд дол. Порівняно 32013 р. зовнішній борг збільшився на 12,9 млрд дол., тоді як внутрішній борг знизився на 7,6 млрд дол.

Відповідно до Бюджетного кодексу України, загальний обсяг державного боргу та гарантованого державою боргу на кінець бюджетного періоду не може перевищувати $60 \%$ річного номінального обсягу валового внутрішнього продукту України. Якщо ця межа буде перевищена, то країні може загрожувати дефолт. Дані табл. 7 свідчать, що в Україні спостерігається загальна тенденція до збільшення співвідношення обягу державного боргу до ВВП. До 2014 р. ця частка знаходилася у нормативному режимі. Після 2014 р. обсяг державного боргу перевищив 60\% ВВП і зростав до кінця 2018 р. та на початку 2019 р. не входів у допустимі межі. В умовах економічної кризи і нестабільної політичної ситуації в Україні зберігається велика можливість дефолту.

Зовнішній державний борг виснажує фінансові ресурси України, змушує ії позичати ще більше, хоча б для того, щоб розраховуватися за вже отриманими кредитами. У 2018 р. зобов'язання за зовнішнім боргом становлять 3,9 млрд дол: 2,05 млрд. - на повернення тіла кредиту і 1,59 млрд - на обслуговування відсотків. Ці зобов'язання покривалися коштом видаткової частини бюджету в 11,4\% видатків. У 2017 р. цей показник був 5,2\%. Тобто 84,3\% приросту держбюджету в 2018 р., який становить 4,3 млрд дол., пішли на погашення зовніш- 
нього боргу. У наступних роках буде ще цікавіше. У 2019-2020 рр. потрібно буде віддати по 6,5 млрд дол. за кожний рік. Через борг у 2015-2016 рр. Україна 3 2021 р. повинна сплачувати податок на економічне зростання у розмірі 15\%, якщо приріст зростання ВВП буде в інтервалі 3-4\%, і 40\% від кожного відсотка зростання, що перевищує 4\%. Якщо економіка України зростатиме в середньому на 5\% у 2021-2040 рр., це становитиме сумарно 21,51 млрд дол. Україні з ії величезним відставанням, щоб за рівнем розвитку догнати країни Східної Європи, необхідні мінімум 7\% щорічного зростання протягом 15 і більше років. У такому разі в 2021-2040 pp. Україні за погодженими інструментами відновлення вартості доведеться виплатити 64,62 млрд дол.

Доцільно порівняти боргові обов'язки України з різними, у тому числі й провідними, країнами світу. Для аналізу використовувалися матеріали, Свростату, МВФ, Держстату України. Заборгованість сильної економіки, наприклад США чи Японії, й економіки слабкої, як України, відрізняється негативними явищами за своїми наслідками. Вважається, що чим вище ВВП країни, тим менше їі зовнішній борг, i, навпаки, якщо ВВП низький, зовнішній борг є високим. Але це не зовсім вірно. Справа в тому, що державний борг не враховує зобов'язання інших країн перед державою-боржником (у нашому разі країни з низьким рівнем розвитку і нестійкою валютою, до яких відноситься й Україна). Тобто в слабо розвинутих країнах у сумі державного боргу не враховуються взаєморозрахунки, тому критичний борговий поріг у слабо розвинутих країнах низький. Водночас до держав-боржників належать такі високорозвинуті країни, як США, Японія, Великобританія, Німеччина, Австрія та ін. У Люксембургу, наприклад, співвідношення зовнішнього боргу до ВВП становить 3 600\%, Швейцарії-417\%. Нідерландах - 700\%, Великобританії-314\%, Японії - 261\%, США - 106\%. Перелічені та низка інших країн самі є міцними кредиторами і під час обліку взаєморозрахунків у них частіше буває позитивне сальдо. Сильні країни можуть позичати, оскільки їхні конкурентоздатні економіки завжди генеруватимуть достатні кошти для розрахунків. Однак слабкі повинні бути значно обережнішими, бо над ними висить загроза неспроможності розрахунків через експортну вразливість чи слабкість, а отже, і дефолту чи диктату кредиторів.

Економіка України, на жаль, слабка. Її товарне виробництво не диверсифіковане, а експорт уразливий через високу залежність від цін на сировину: пшеницю, соняшникову олію, металопрокат та напівфабрикати зі сталі, залізорудну сировину і кукурудзу, на які припадає близько 50\% товарного експорту країни. Україна знаходиться в постійній політичній та економічній кризі, має нестабільну економіку і не може рівнятися за рівнем державного боргу з перерахованими країнами. Україна за своїм економічним станом $\epsilon$ країною, якій отримання нових позик у міжнародних фінансових інститутів стає вже складною проблемою. Нові зовнішні борги України, як правило, йдуть на погашення старих боргів і відсотків за ними, на формування Пенсійного фонду, на погашення боргів із заробітної плати та інші внутрішні потреби, але ні в якому разі не на розвиток економіки. Під час формування зовнішнього боргу Україні слід бути дуже обережною. Керуватися треба не інтересами окремих осіб, не короткостроковими потребами, а довгостроковою економічною стратегією. За образним виразом директора ДП «Укрпромзовнішекспертизи» В. Власика, «начебто тиха і непомітна зовнішня заборгованість поступово перетворюється на дракона, що висмоктує критично важливий фінансовий ресурс, блокуючи економічний розвиток і беручи у полон енергію майбутніх поколінь. Потрібна термінова зміна підходів до економічної стратегії. Потрібен загальний план економічного розвитку, захищений від популізму і короткострокових інтересів політиків. Потрібно, щоб місце зовнішньої допомоги випливало із власного плану, а не вимоги зовнішньої допомоги диктували внутрішні економічні рішення».

Висновки. За роки незалежності Україна не змогла подолати труднощі перехідного до ринкових відносин періоду. Погіршилися всі макроекономічні показники, знизився рівень життя населення. Руйнування економіки призвело до втрати суверенітету як в економічному, так і в політичному аспекті. Економіка держави тримається на кредитах міжнародних фінансових інститутів, основна частина яких іде на погашення процентів. Державний борг постійно зростає. Система кредитування МВФ збудована так, що за зростання ВВП більше ніж 3\% проценти за кредит пропорційно зростають, що знижує ефективність стимулювання економічного зросту та перетворює Україну на постійного боржника. Багато країн, що успішно розвиваються, вже давно відмовилися від кредитів МВФ і активно ведуть свою економічну інвестиційну політику, яка спрямована на підвищення продуктивності праці, збільшення обсягу внутрішньої продукції та високої частки доданої вартості. Україні також слід орієнтуватися на передовий досвід країн, які розвиваються, тим більше що всі базові складники для випуску високотехнологічної продукції практично в усіх галузях виробництва у нас $€$.

Список літератури:

1. Бураківський І., Мовчан В. Аналіз соціально-економічних наслідків членства України після трьох років членства: очікування і реалії. Київ : ІЕДПК, 2011. 58 с.

2. Геєць В.М. Пріоритети національного економічного розвитку в контексті глобалізаціонніх вікліків. Київ : Нац. торг.-екон. ун-т, 2008. 389 с.

3. Офіційний сайт Міністерства фінансів України. URL : http//www.minfin.gov.ua/

4. Офіційний сайт Міністерства економічного розвитку и торгівлі України. URL : http//www.gov.ua/

5. Офіційний сайт Державної служби статистики України. URL : http//www.gov.ua/ 


\section{References:}

1. Burakivskyi I., Movchan V. (2011) Analiz sotsialno-ekonomichnykh naslidkiv chlenstva Ukrainy pislia trokh rokiv chlenstva: ochikuvannia i realii [Analysis of socio-economic consequences of Ukraine's membership after three years of membership: expectations and realities]. Kyiv: IEDPK, p. 58.

2. Heiets V.M. (2008) Priorytety natsionalnoho ekonomichnoho rozvytku v konteksti hlobalizatsionnikh viklikiv [Priorities of national economic development in the context of globalization challenges]. Kyiv : Nats. torh.-ekon. un-t, p. 389.

3. Ofitsiinyi sait Ministerstva finansiv Ukrainy [Official site of the Ministry of Finance of Ukraine]. Available at: http//www.minfin.gov.ua/

4. Ofitsiinyi sait Ministerstva ekonomichnoho rozvytku y torhivli Ukrainy [Official site of Ministry of Economic Development and trade of Ukraine]. Available at: http//www.gov.ua/

5. Ofitsiinyi sait Derzhavnoi sluzhby statystyky Ukrainy [Official site of the State Statistics Service of Ukraine]. Available at: http//www.gov.ua/

\section{МАКРОЭКОНОМИЧЕСКИЕ ПОКАЗАТЕЛИ РАЗВИТИЯ УКРАИНЫ}

Статья является одной из ичикла статей, которые анализируют развитие Украинь за период независимости 1992-2018 г2. Предполагается исследовать макроэкономические показатели, экономические показатели отраслей реального сектора экономики Украины, систематизировать причины неудач и оценить возможности эффективного вхождения Украины в рыночную экономику. Исследуется тенденция развития экономики Украины на базе основных макроэкономических показателей. Выявлены причины стойкого снижения численности населения, его реальных доходов, ВВП, роста государственного долга, ухудшения платежного баланса. До получения политической и экономической независимости Украина занимала одно из ведущих мест среди европейских стран. Неподготовленность власти к рыночной экономике привела к глубокому кризису управления и, как следствие, к краху экономики. Для разработки долгосрочной, научно обоснованной сочиально-экономической стратегии выхода из экономического кризиса необходимо провести качественный комплексный анализ украинской экономики в период независимости, выявить тенденции, реалии, причины неудач, определить ресурсы и возможности, а затем обозначить приоритетные направления выхода Украины из продолжстельного кризиса.

Ключевые слова: территория, население, реальные доходы, валовый внутренний продукт, бюджет, платежный баланс, государственного долг.

\section{MACROECONOMIC SHOWERS THE DEVELOPMENT OF UKRAINE}

The article is one of the series of articles that analyze economic development of Ukraine during the period of independence of 1992-2018 biennium, which provides for the study: macroeconomic pokazniki, economic pokazniki branches of the real sector of economy of Ukraine, To systematize the reasons of failures and to assess the possibility of Ukraine's effective entry into a market economy. This article examines the macroeconomic level of Ukraine's development. The tendencies and the main causes of steady population decline, its real incomes, GDP, the growth of public debt, deterioration of payments balance were shown. Ukraine is one of Europe's most European countries, possessing powerful territorial, natural geographical, human, industrial, transport and agricultural potential. Before gaining independence, it took 5 meesto in Europe by the volume of gross domestic product. For the successful self-sufficiency development of Ukraine lacked all: a variety of natural resources, almost all the elements of the table are in bowels Ukraine, most fruitful black, a large array of forest grounds, The geographical location of international transport links is extremely favourable. Industry of Ukraine was represented by a full range of industries-from mining and ending with high-tech industries like shipbuilding, aerospace, instrumentation. Large volume of production is performed by enterprises of the military industrial complex. Trade and economic, scientific relations of Ukraine led with most countries. In Ukraine, formed a highly skilled production and scientific and technical potential. Therefore, in Ukraine, with the acquisition of independence, there were all chances for the rapid achievement of economic and social standards, in which the country does not need to be asked in the EU, and their invites to European cooperation on the rights of an equal member. There are many examples, when completely destroyed in the period of 2 World War II country in 5-7 fully restored its economy and reached a higher than in the secondfull period of indicators. In Ukraine, the cob of the awakened-no. In the yacosty incentive factor for the reach of the European standard in Ukraine, credit was given to the Ukrainians. Sorry Ukraine, Yaka has easily rejected the independency, and has stymied the SRSR want to grow old, and the need for modernity, ale all the squirming of the virobnyeconnomic shadly, by virtue of a number of ob's, the great-sum Vikoristovati z'i've been wide, she's got a wide picture of himself, and she's been able to see all the economic ostentatious. The government's unprejudicial power has led to a deep crisis of management and, consequently, to the collapse of the economy. To develop a long-term, scientifically grounded socio-economic strategy for the exit from the economic crisis, it is necessary to make a qualitative, comprehensive analysis of the Ukrainian economy during the period of independence, identify trends, realities, causes of failures, identify Resources and opportunities, and then designate the priority directions of Ukraine's withdrawal from the delayed crisis.

Key words: territory, population, real incomes, gross domestic product, budget, balance of payments, state debt. 